\title{
Authorial Reading as a Phenomenon of Personality Development Stanislav Suda
}

\begin{abstract}
Authorial reading as a phenomenon of personality development - the aim of the article is to point out the broader pedagogical context of writing originally artistic authorial texts. It will present, in a broader sense, a long-term qualitative, participatory, and partner research of experimental drama which also includes authorial reading. It also illustrates the possibilities of written self-reflection as a control feedback of the pedagogical process from the point of view of personality development. It outlines the possibilities of self-reflection improvement which is based on the experience of the phenomenon of authorial reading within personality development.
\end{abstract}

Keywords: pedagogy, personality development, authorial reading, dialogue, self-reflection

\section{Introduction}

Thanks to its founder, Ivan Vyskočil, experimental work based on authorial reading has been taking place at the DAMU Department of Creative Writing and Pedagogy in Prague since 1994. When thinking about research evaluation, this discipline was, in the broader research of experimental drama, ${ }^{1}$ included in the possibilities of personality development at the Department of Pedagogy and Psychology, Faculty of Education, University of South Bohemia in České Budějovice. For the last two years, together with philosophy for children and experimental drama, it has been the basis of personality development of the study course Leisure Time Education at the Department of Pedagogy, Faculty of Theology, University of South Bohemia in České Budějovice. The first chapter of this article is narrative, autobiographical. Its aim is to point out the broader pedagogical context of writing originally artistic authorial texts.

\section{Motivation to Study Authorial Reading}

In basic school (6-15 year olds), we had a real educator as a class teacher. I emphasise the word educator. We were students of a selected class and our teacher, Mrs Lašková, was very challenging.

1 Cf. Stanislav SUDA, Psychosomatické disciplíny v přípravě učitelů, in: Psychosomatické disciplíny v př́pravě pedagogů, ed. Pavla Valachová, Brno: Paido, 2008, p. 49. 
And even if she was demanding a lot, we knew that 'Lajda' meant it in a good way - as a teacher of Czech and English, as a class teacher, as a human being. Until her death, we met her regularly. As her students, we meet regularly to this day. I remember her most often when speech turns to essays. Writing essays was a joy. She supported us a lot in speaking, in informal, live speech. I remember a lot of moments when we enthusiastically listened to the creations of our classmates. How she literally forced us into dramatic situations, using direct speech, and dialogues in storytelling. One of my classmates made her very happy with a perfect description of a disassembled TV together with a description of a repairman and his unfinished beer next to the device. Writing 'essays' was actually a challenge and also a joy. When I entered grammar school, I thought that I would expand this space much more thanks to high school teachers.

Of course, I wrote my first essay, quite understandably, on the topic of holiday experiences. It was full of direct speech, expressive, dramatic, about a trip of friends on bikes - I was absolutely happy with it. And I was given a C minus. I recklessly used words like 'he flew over the handlebars'. In direct speech, I cursed - 'you ass!' And in general, according to the new teacher, I was somehow suspiciously relaxed and very action-packed when considering the fact that I was a first-year student. In the second essay, we had the task to write a story about some sad accident. I wrote about a carefree ride of a young man who was showing off in a new car. He skids in oil and runs over some children. At the age of fourteen, I had done my best - those at home liked it and I successfully read it during the breaks at school. Only my teacher stopped me after the first few sentences and I was not allowed to finish it. In her opinion, the beginning could not be recited with such ease when there was death at the end. I could not even speak. In the fourth year, I rather wrote about Pilsen, my home-town, where one can see young people sitting on benches without the first experience of love. And there are also some retired people, a grandmother and a grandfather, who look at them with understanding, holding hands in the glow of the setting sun, also sitting on a bench. I received A+, and my graduation result was excellent. Coincidentally, the husband of my primary school class teacher was a teacher of Czech at the same grammar school. We had a lot of fun during our meeting. He recounted how he had secretly written an essay for his son and received D from the same professor. The lady was not really bad, though. She just lived alone, some of her views were somewhat narrow-minded, and she simply lived her special life. Every time I think about it, I find it somehow a little funny, sweet. While feeling this way, I realise that, after that, I did not write a word for ten years. And if I hadn't met Professor Vyskočil at DAMU, I probably would not have written or tried anything in my life. I am not angry with the teacher at all, I understand her. And I even try to suggest to myself that it was definitely useful to me. But I did not really imagine it that way; I would not want it that way for anyone, including myself. The most interesting thing was that the majority of my high school classmates did not have such thoughts at all. They were used to writing evaluated essays. They knew what should be 'written', and they were already trained during their elementary school years in this way of working. They knew exactly that writing was actually rather a duty with no fun, that it just had to be endured. They never read their work to their classmates, and if they did then it was in a formal way. These are the rules. The topic is always given and the scope is determined. You have to create the structure: introduction, body, and conclusion (which almost everyone constructs after writing). Essays are graded by the teacher, and you usually do not even know what and how your classmates write. In fact, you should not care much. Teaching of writing in this way tells us that writing essays is a test of formal language skills. And it should be standardised in order to objectify the evaluation. Honestly, when someone deviates from the average, there is a problem with the evaluation. Also, 
what it would look like if everyone wrote what he wanted! It is true, I went to high school in the first half of the eighties, during totalitarian education. But has much of it really changed since then?

Authorial writing and reading is not about art, or whether we can write and read well or not. This process is about learning to share through speech. Rather, it is a matter of recording things we enjoy, things which interest us, disturb us, or questions which we ask. In public reading, it is about learning to listen to one's own texts and then be able to understand them. To do this, one needs to be in touch not only with one's own text, but also with oneself and the audience. ${ }^{2}$

Professor Ivan Vyskočil told us in the instructions at that time: 'Write what you want.' He did not evaluate, and did not order the content, topic, or length. When reading one's own text in public, one learns for oneself if the text is communicative. After the initial shock from the assignment and after the experience of nervousness from the first reading of our own authorial experiments, we began to find out that we can communicate for ourselves, that we can write serious, unserious, longer, shorter, unusual, absurd, and even 'stupid' texts. No one marks them and evaluates the quality. As students, we learn about it from the attention of listeners, classmates - very aptly and accurately. Someone really listens to you and your texts and comments on them using his own experience in order to describe how he understands your text and what has been created in it this creates an atmosphere of security. It relieves the fear that the comments will turn into critical condemnations. And you also know that, next to you, there is an unquestionable pedagogical authority. He accompanies you in your attempts, mistakes, and successes. Over time, the most determined of us even began to perform regularly in public with our own shows.

\section{On the Philosophy and Methodology of the Research}

Positivist-oriented pedagogical research does not currently study the influence of the phenomena of play, art, or authorship on personal human knowledge. The current grant schemes usually prefer three-year projects. Lack of time (as well as focusing on the goal, its objectification, and extraction or interpretation of data) is a major challenge for studying the impact of these phenomena. Therefore, we have to look for ideas in foreign literature. In domestic professional literature, we should look more in the field of psychology or art research.

Among the foreign researchers, Max van Manen is currently one of the most inspiring. His studies are devoted to the research of pedagogical tact ${ }^{3}$ or the meaning of phenomenological research and writing. ${ }^{4}$ Piaget's studies are very inspiring. They were widely published even in the former Czechoslovakia and concern the relationship between science and philosophy ${ }^{5}$ or personality directly. ${ }^{6}$ Subsequently, this type of research and study started developing in our conditions, for example, in the work of experts in psychological experimental research František Jiránek ${ }^{7}$ (translator of Piaget's Psychology of Intelligence) or Eva Vyskočilová ${ }^{8}$ (translator of Piaget's The Psychology of the

2 Ivan VYSKOČIL, Autorské čtení, in: Hlas, mluva, řeč, ed. Michal ČUNDERLE and Eva SLAVÍKOVÁ, Praha: Ústav pro výzkum a studium autorského herectví AMU, 2006, p. 7.

Cf. Max van MANEN, Pedagogical Tact, New York: Routledge, 2016.

Cf. Max van MANEN, Phenomenology of Practice, New York: Routledge, 2014.

Cf. Jean PIAGET, Múdrost' a ilúzie filozofie, Bratislava: Nakladatel'stvo Pravda, 1977.

Cf. Jean PIAGET, Psychologie dítěte, Praha: SPN, 1970.

Cf. František JIRÁNEK, Pedagogická psychologie, Praha: KPÚ, 1968.

Cf. Eva VYSKOČILOVÁ, Cvičení z pedagogické praxe, Praha: SPN, 1978. 
Child). In the last twenty years, under the methodological guidance of Eva Vyskočilová, The Institute for Research into and Study of Authorial Acting at DAMU in Prague has been particularly active. Taking into account the methodological aspect, this long-term participatory research is based on the assumptions of constructivist theory which summarises F. Jiránek - relationships really exist, the individual reveals them by his activity, this activity develops from material to mental activity in connection with the development of abstraction, that is, the ability to have opinions about the world which are increasingly socially conditioned: 'For working with language, this specifically means that the meaning of a word cannot be communicated by pointing to the meaning of the expression. The individual must work on it through his own activities, cooperation with others, especially with adults.9 ${ }^{9}$ Based on this, it turns out that the possibilities of the methodology open up with practical activity (the experimenting with authorial reading itself), studying (reflecting on the activity), and the ability to open self-reflection to a wider social context.

In connection with this, the phenomenologist Jiři Černý points out the fact that we should not focus on what is the phenomenon of play (art, authorship), but on how this phenomenon is with us. ${ }^{10}$ This creates a paradox of a qualitative view of the research of these phenomena - specifically in the case of authorial reading, it is not a research of the 'subject' of authorial reading. The view of research shifts towards the subject. The aim is not to categorise the subject of research. The subject of the research is the phenomenon of authorial reading. So it is not what authorial reading is, but how authorial reading exists among us. For example, how and when do we feel the attention of the audience in the feedback? How do we find out which type of texts corresponds to our nature? How adequate is a particular intensity or speed of reading? ${ }^{11}$ How are body and expression are involved? ${ }^{12}$ These are research questions that concern ourselves, so they do not represent a subject type but a non-subject type. ${ }^{13}$ We need to find out how the phenomenon of authorial reading is perceived by the experimenting subject. The subject is an active factor in the synthesis of experience in experimentation and in the formulation of self-reflection based on feedback from viewers (the abovementioned cooperation with others). If the student is able to formulate a written self-reflection based on the intense experience of his own work, he becomes a priceless partner in the participatory research of this phenomenon. The research thus finds itself on the border of the fields of psychology, pedagogy, dramatic arts, and, through its participation with students, also raises ethical issues.

From this point of view, Vladimír Chrz (Institute of Psychology, Academy of Sciences of the Czech Republic) views it as truly participatory research: "It is "research with people" (rather than research "on people" or "about people"). It is research in which its participants (whether they are in the position of a researcher, the researched persons, or those to whom the research is presented) learn together [knowledge comes through studies]. ${ }^{14}$ Likewise, Eva Vyskočilová was aware not only of the methodological challenge itself but also of the overlap of this study and research on ethical issues. The essence of long-term self-reflection lies not only in the description and analysis of the author's activity but also in the increase of interest in the author's actions related to the increase of self-confidence and independence. 'From the lifestyle point of view, it is about his

9 František JIRÁNEK et al., Otázky psychologie učení, Praha: SPN, 1970, p. 72.

10 Cf. Jiř́ ČERNÝ, Fotbal je hra (pokus o fenomenologii hry), Praha: Československý spisovatel, 1968, p. 11.

11 Cf. ČUNDERLE and SLAVÍKOVÁ (eds.), Hlas..., pp. 7-120.

12 Cf. Eva VYSKOČILOVÁ and Eva SLAVÍKOVÁ (eds.), Psychosomatický základ veřejného vystupování, jeho studium a výzkum, Praha: AMU, 2000.

13 Cf. Ladislav HEJDÁNEK, Nepředmětnost v myšlení a ve skutečnosti, Praha: Oikoymenh, 1997.

14 Vladimír CHRZ, Předmluva aneb Co je vlastně experimentální dramatika, in: Experimentální dramatika, Stanislav SUDA, České Budějovice: Epistéme, 2017, p. 13. 
higher value focus related to a greater degree of the student's sense of responsibility but also to the internal balance. ${ }^{15}$ Changes are observable due to the distribution over time.

\section{On the Goals and Meaning of the Research}

Given that the Institute for Research into and Study of Authorial Acting at DAMU in Prague and at the University of South Bohemia in České Budějovice runs a long-term research project into the phenomenon of dialogue with internal partners (a certain author's way of improvising without specifying a situation, topic, or text) ${ }^{16}$ we can be inspired by the results of these years of research in the field of methodology, ${ }^{17}$ art-pedagogy (a fifteen-year case study) ${ }^{18}$ or in the psychological-psychiatric field (a twenty-year case study). ${ }^{19}$

The aim of pedagogical (or therapeutic) work and the subsequent collection of research data is to obtain evidence of the inner experience of specific participants. In this way the statements can authentically capture the researched phenomenon. It can often be an unprofessional, naïve, or metaphorical testimony with personal or artistic overlap. However, from this partner research point of view, any authentic statement seems to be very valuable, and it is inadmissible to interpret and evaluate it in any way. Participants would thus become objects of research 'on people' or, in a better case, 'about people.' Due to the required continuity of activities and continuation of the study (distribution over time), students could be influenced by the researcher's interpretations and evaluation attitude or could lose interest in studying. And research can only take place if the participants themselves feel their own interest, desire, or even the need to experiment with authorial writing and, especially thanks to authorial reading, they perceive the need to clarify their own attitude. Therefore, authorial reading is always included as an optional subject or one chosen from a list of compulsory possible alternatives. Longer case studies thus arise only within the framework of study in free time. Participants from the public or graduates of full-time studies (in the study courses which offer this discipline) take part in it.

In terms of research focus and the methodological and philosophical approach outlined above, it will be more advantageous to talk about the meaning of research than about the goals of research. ${ }^{20}$ If it is to be a real participatory and partner research, then the partial goals of the research are created by individual participants. They describe the phenomenon from angles that interest them. They themselves add meaning to the phenomenon and its interpretation according to their own interest, experience, and ability to formulate reflection with an overlap to self-reflection. ${ }^{21}$ The most important work of the researcher is to open this space for experiment and subsequent reflection. In this sense, he also guarantees that individual participants will not be evaluated, scaled, or categorised according to effectiveness or contribution to scientific or artistic goals. We can set goals for individual sub-surveys.

15 Eva VYSKOČILOVÁ, K některým metodologickým obtížím výzkumu autorského herectví, in: Hic sunt leones, ed. Michal ČUNDERLE, Praha: AMU, 2003, p. 129.

16 Cf. Ivan VYSKOČIL, Dialogické jednání s vnitřním partnerem, Brno: JAMU, 2005.

17 Cf. Josef NOTA, Zkušenosti ze studia disciplíny „dialogické jednání s vnitřním partnerem“, výpovědi pedagogů, in: Diverzita $v$ spoločenských vedách, ed. Radomír MASARYK, Magda PETRJÁNOŠOVÁ and Barbara LÁŠTICOVÁ, Bratislava: Ústav výskumu sociálnej komunikácie SAV, 2012, p. 249.

18 Cf. Stanislav SUDA, Tělo a sebereflexe, in: ed. PhD existence 9 - Tělo a mysl, Eva MAIEROVÁ, Lucie VIKTOROVÁ, Martin DOLEJŠ and Tomáš DOMINIK, Olomouc: UPOL, 2019, p. 42.

19 Cf. Stanislav SUDA, Psychiatrická kazuistika - 20 let s experimentální dramatikou, in: PhD existence 10 - Člověk a čas, ed. Eva MAIEROVÁ, Lucie VIKTOROVÁ, Martin DOLEJŠ and Tomáš DOMINIK, Olomouc: UPOL, 2020, p. 168.

20 Cf. Viktor Emil FRANKL, Vưle ke smyslu, Brno: Cesta, 2006.

21 Josef NOTA, Proměny reflektování v čase: od reflexe disciplíny dialogického jednání k sebereflexi, in: PhD existence 10 - Člověk a čas, ed. Eva MAIEROVÁ, Lucie VIKTOROVÁ, Martin DOLEJŠ and Tomáš DOMINIK, Olomouc: UPOL, 2020, p. 144. 


\section{Authorial Reading in Pedagogical Study Courses of the University of South Bohemia}

In 2008, the first survey focused on authorial reading and its research was conducted. Methodologically, an experiment was chosen following the example of the abovementioned research into the phenomenon of dialogic acting. The sample consisted of 70 full-time students of pedagogical courses at the University of South Bohemia in České Budějovice. Experience with research into the phenomenon of dialogic acting ${ }^{22}$ has shown that a group of statements appear in compulsory courses expressing students' fear of public authorship or acting. These are statements in which a higher degree of anxiety appears, and the participants displace or reject the phenomenon. It is strange situation considering the fact that these are students of pedagogical disciplines, but this is a fact.

These students cannot self-reflect themselves and thus cannot testify about the phenomenon. In order to avoid study and research misunderstandings in the authorial reading, students were selected for the survey within the optional subjects area only. This at least partially fulfilled the requirement of a partner approach and independence from evaluation. Successful completion of the course consisted, as in the case of dialogical acting, in attendance, activity, and the submission of a non-evaluated final written text, that is, a self-reflection. ${ }^{23}$ After the semester's teaching, and the creation and reading of at least five authorial texts, students were invited to write a self-reflection as a free form. The basic question was the effort to find out whether and possibly in what number students understand authorial reading as a personality discipline. Based on these statements, two basic groups of statements were created. They were arranged according to the participants' ability to speak publicly using their own text.

The first group was characterised by the expression of initial fears. These, however, subsided within one semester and became, as did the nervousness of the students, milder. In this way, the experience with the authorial reading was reflected by 50 authors who also positively evaluated their progress within one semester.

The second group consisted of 20 self-reflections. Students described a certain overlap, and there was an attempt to describe what exactly happens in each of the students during public reading. This ratio also corresponds to the fact that 20 students found the courage to provide some of their texts for publication in the proceedings. An example of self-reflection from 2007:

... Finally, there were listeners who told me their opinion on my 'works'. I finally found out that maybe I am able to write a little, that it's not so bad with me, and that I can say my thoughts in Czech. And on the other hand, I could listen to everyone else. I was incredibly surprised by their thoughts and ideas, and I thought 'Yes, this is absolutely great, it is a great idea, a great topic!!' In fact, to sum it up, I admired all my classmates, their dialogues, short stories, comments, observations of life itself. I must say that I admired myself as well. There were so many ideas to write, so many situations, problems, thoughts... However, it is true that it was difficult to write them, to take a piece of paper and a pencil and start writing them all down on paper and, most importantly, to express them as

22 Stanislav SUDA, Dialogické jednání - vyhodnocování reflexí, in: Acta Universitatis Palackianae Olomucensis, Psychologica 37 Supplementum, Kvalitativní prístup a metody ve vědách o člověku VI., Olomouc: UPOL, 2007, p. 168.

23 Stanislav SUDA, Nedirektivní vedení dialogického jednání s vnitřními partnery, in: PhD existence III., ed. Aleš NEUSAR, Miroslav CHARVÁT, Martin DOLEJŠ, Denisa JANEČKOVÁ and Roman PROCHÁZKA, Olomouc: UPOL, 2013, p. 102. 
accurately as I would have imagined. I know that I didn't succeed at times, but at least I found out about my mistakes, i.e., I realised that I have to go for it from the other side or with a completely different topic. On the other hand, I also know that I succeeded. There were more successful ideas, and I am happy about that... I already know a little bit about self-reflection. I mean the way it works for us, what can be expected from it, and its reaction in different situations. It is amazing to see its influence on us. It is actually nice to have it.

\section{On the Methodology}

This investigation was the first step in discovering the possibilities of the methodology regarding the phenomenon of authorial reading according to Jiránek's scheme. This phenomenon exists, and students discover it with their own activities and try to describe its influence. This verified that the study of the phenomenon within the artistic-pedagogical discipline is possible. Throughout the long-term research of experimental drama, which includes (in addition to the investigated phenomenon of dialogical acting) the study and research of authorial reading, these statements (a kind of research data) are stored in the archive. We are currently talking about thousands of stored statements that are available for retrospective comparative investigations at any time. ${ }^{24}$ In particular, it is an ongoing assessment of whether the study and research is running for students who are capable of this study.

At present, long-term research for the study course Assistant for Schools at the University of South Bohemia in České Budějovice is also underway. Regarding non-directivity, study partnership, and participation, the study model of optional methodological specialisations is very successful. Students pass individual specialisations (personal-social education, experiential pedagogy, reflection of religious values in education) throughout the semester and then choose a selected specialisation with a specific teacher for a three-semester targeted study. For the purposes of the control survey, self-reflections of 15 students were selected on the basis of semester teaching of the discipline of authorial reading in the academic year 2019-20.

Due to the optional character of the methodological specialisation, students who do not want to study authorial reading, that is, those who would feel anxiety or who would reject or displace it, do not enter this part of study. The ratio of 2:3 can be deducted from the submitted statements within the abovementioned division of groups.

The first group again included statements that expressed more anxiety and nervousness.

... After examining the terrain and surrounding conditions in the form of my classmates, I came to the conclusion that I really do not have to feel like in a glass shop window. I should focus on myself, my feelings, and try to relax in front of the 'crowd' of people which I want and maybe I have to get interested. Feelings of relaxation and a less sweaty T-shirt appeared at the end of the semester. I might have an opportunity and promise for the future...

... I am very shy. Sometimes I am so nervous that I have icy hands and feet. At the same time, my head burns as if I have a fever, and my heart is pounding like crazy. No, I am not exaggerating. I have been fighting stress for a long time. My favourite sentence is, it is nothing serious ... but it never helps

24 Cf. Milena MATĚJÍČKOVÁ, Josef NOTA, Stanislav SUDA, Observing Qualitative Changes in Psychosomatic Condition, The New Educational Rewiew 24/2011, p. 147. 
me completely. Good deep breathing can help too, but I do not want to breathe heavily in the class either. So I still have to grit my teeth and handle it. I have no choice. And then, during the situation which was so stressful for me at the beginning, I sometimes enjoy it. For example, as our authorial reading...

A very similar level of concern as in these two testimonies was recorded in the other four testimonies.

This time, nine statements were included in the second group. There is a noticeable study potential of these students. By way of illustration, we present passages from the self-reflection of three students.

... I wanted to move somewhere further during these classes. I was surprised, though, as it was a problem for me at the beginning. It was strange considering the fact that I had had the practice of talking in front of 90 people at summer camps without any problems. But obviously there is quite a difference between explaining the rules of a game or speaking to a group of kids and reading aloud one's own authorial text. So, in conclusion, I would like to say: Thanks for the non-violent force which made me work with myself and push the boundaries of my comfort and social-zone a little further. I'm already looking forward to the next semester and its programme...

... Since basic school, I have not liked writing stylistic work and various multi-page essays. There was always an assigned topic, or we had to choose from several listed topics... After a long time, someone gave me a free hand and opened my imagination. Somehow, I started to guide myself in the area of my thoughts. I realised a lot of things and make them clear for myself. Simply, when I had something on my mind, it usually appeared in my writings as well. Whether it was the idea that people should spend more time with family, or that every little kindness and help can make a better day. It was not the biggest obstacle to figure out the best topic for myself, or the writing itself. The problem was, I would say, the presentation of our own text...

... Although it may not look that way at all, I feel a lot of progress on my own. The others may not even notice, but it was this step out of the comfort zone, the feeling of visibility in front of everyone, exposing oneself to criticism or embarrassment that finally allowed me to grow in some way. When I have to present anything in front of others at school, express my opinion, or just present my thoughts, the previous problems no longer happen. I don't think about things which could happen, which could go wrong, and that I will DEFINITELY ruin it. I believe I can do it, because it has happened before. Just because I tried it and was not afraid of WHAT IF. I started using either yes or no. Either it will work out and I will be proud of myself, or it will not work out and nothing will happen. In the latter case, I will start thinking about how to improve myself, how to do it differently. Now I see that my text looks a bit like the headlines in a weight-loss motivational video. Excuse me, but I need to comment on this a little. I just (I am sorry for the thousandth time, I don't know how to put the sentence together), I started to believe more in myself. It has never occurred to me how reading texts or standing in front of a class could affect my personal life. I can say for sure that it did. And a lot. It affected me so much that I gradually started to get rid of what I fear the most, the 'Scarecrows'. It was done simply by doing what I was afraid of. And who would have thought that not even a minute of standing in front of my classmates would help me with all of this. And I am looking forward to what 
will come next. What do I dare? Maybe I will decide to talk, to show something. Who knows? I am beginning to realise how my self-confidence and fear that something could go wrong, that I would not be as good as expected restricted my freedom so madly. This is why I stop trying to look the way I am expected in front of others. I am just trying to be myself. I do what I enjoy, I say what I think, and I am not thinking so much about how others see me. Whether it was embarrassing, weird, or crazy. And in fact, I started to enjoy trying out the uncertainty, playing with feelings and emotions.

These ongoing surveys are used to control the usefulness of the study on the basis of the methodological condition concerning the optional character of studies. This also verifies Jiránek's thesis ${ }^{25}$ that in creative study it is about interest, need, and attitude. These are far more important than skill, habit, and application.

\section{Study of Aspects of Authorial Work}

These self-reflections also refer to the suitability of connecting the discipline of authorial reading with dialogical acting (the abovementioned certain authorial way of improvising without specifying a situation, topic, or text). They discover the possibility provided by the study of dramatic situations and authorial acting. Students begin to realise that, in a safe space, they can dare to enter uncertainty and try to act out emotions. On the basis of feedback, they can find out the authenticity of their own expression.

Due to the mentioned specificity of non-standardised statements, we methodologically approached a qualitative study within the bachelor thesis, ${ }^{26}$ masters thesis ${ }^{27}$ and a prepared doctoral project. ${ }^{28}$ Its results are published here for the first time. As part of these surveys, an effort was made to find out the authors' feelings during writing, the effects which public reading has on them, and the content which is projected into their texts.

The research was divided into two parts. In the first part, five in-depth semi-structured interviews were conducted. They were subsequently analysed using open coding. This process was then followed by the technique of card sorting. Within this part, a simple deliberate selection of the sample was chosen. The condition was the completion of at least two semesters of authorial reading, as it takes time before the initial nervousness subsides and the author is able to deepen his self-reflection. Four women and one man took part in the interview. This ratio corresponded to the actual gender distribution of the authorial reading participants. The second part of the research was formed by the students' self-reflections which were completely unstructured. Self-reflections from 2007, 2008, 2010, 2011, and 2013 were analysed. As there was no criterion, self-reflections of students who completed only the first semester of authorial reading appeared quite often. The method of analysis was similar to the interviews and a total of 178 self-reflections were part of the research, where the ratio of men and women again corresponded to the actual distribution within the subject. As part of the analysis of in-depth semi-structured interviews, we obtained a total of 11 categories. From the analysis of unstructured self-reflections, 15 categories emerged.

25 Cf. JIRÁNEK, Pedagogická psychologie...

26 Cf. Renáta MIKULOVÁ, Psychoterapeutické aspekty autorské tvorby. České Budějovice, 2015. Bachelor thesis (BA). University of South Bohemia in České Budějovice. Faculty of Education. Thesis supervisor Dr Stanislav Suda.

27 Cf. Renáta MIKULOVÁ, Autorské čtení - studie osobnostních aspektů. České Budějovice, 2018. Diploma thesis (MA). University of South Bohemia in České Budějovice. Faculty of Education. Thesis supervisors: Dr Alena Nohavová and Assoc. Prof. Stanislav Suda. 
After three years, the research was repeated. Based on the abovementioned findings, a qualitative study was performed which was divided into two main parts. The first part represents the analysis of in-depth semi-structured interviews. We obtained a total of seven interviews $(n=7)$. There were five women and two men aged 22 to 35 years involved. A criterion was chosen in the form of completing at least three semesters of authorial reading at PF JU. The interviews were analysed using open coding. We sorted the resulting categories according to the frequency of the codes, and we interpreted them using the card sorting. The result was a total of 22 categories. The second part of the research is the analysis of written student self-reflections. We selected a total of 236 self-reflections $(\mathrm{n}=236)$. They were written by 198 women and $38 \mathrm{men}$. Reflections were collected in 2012-16, and no criteria were selected for the selection. The result was a total of 14 categories. These were then compared with the categories which were obtained in the analysis of interviews.

Thanks to the unstructured character of self-reflections, we obtained some categories which were not in the area of our primary focus. The main purpose of this research was to explore and map the area of authorial reading, as there is not much knowledge of this area so far. We found that the authors mainly perceive writing texts and their subsequent reading in public as a possible way of self-expression and an opportunity for personal development. The latter mainly lies in reducing nervousness and fear, improving oral and written expression and, last but not least, in increasing the author's confidence.

Based on a comparison of both research surveys, we established ten important categories.

\section{Interpretation of the Most Important Categories}

Projection of current states and contents. This category applies to everything that authors project into their texts. We most often encounter current experiences, thoughts, feelings, and events from the author's life, both in a positive and negative sense. It is no exception that the authors, through their texts, express opinions or feelings that they would not express in public otherwise. They use writing in the $3^{\text {rd }}$ person, metaphors, or abstractions.

Expectations of negative reactions. The category called 'expectations of negative reactions' is directly related to the previous category. Because the authors perceive their texts as personal, often intimate, and have not been accustomed to presenting anything of their own to the public, there is a great deal of expectation of negative reactions to their work. The most common negative reactions that the authors expect are misunderstanding, rejection, ridicule, or being cut off. What we initially encounter, in the case of almost all authors, is the fear that their text will not be communicative.

Freedom and fear of freedom. Within this discipline, the authors are not limited by anything. Their only task is to write a text. They have no topic, feature, or minimum or maximum text length specified. Most authors are initially paralyzed by this freedom, but later it motivates them to continue in their writing. The authors describe it as a choice of their own topic, non-binding, or open-mindedness. Within the written self-reflections, however, one group of authors could not overcome the initial paralysis caused by this freedom. Their fear is described as a certain block which does not allow them to write a text and causes them distrust, insecurity, limits their sense of security, and, on the contrary, strengthens the expectation of negative reactions. These authors express the need for some guidance or direction.

The theme of nervousness. In almost every self-reflection and conversation, we encountered the topic of nervousness. Authors are not initially sure of their texts and do not have much courage to 
try or search for new forms. So, it usually accompanies everyone, at least in the beginning. Most often, nervousness manifests itself as an overly fast pace of reading.

Self-expression and fear of self-expression. This category is closely related to freedom. Many authors are motivated to write and read their texts precisely because they are given the opportunity to produce something that is based on their personality, that is only theirs. In most cases, the possibility of self-expression is understood positively. But even within the self-reflection, there is a group of authors who show concerns about self-expression. These authors are afraid of revealing themselves to other authors. Again, for them, such fears are a block that prevents their authorial work.

Within the framework of self-reflections, several important categories appeared which we did not encounter during the interviews. This can be explained by the fact that, in interviews, a certain criterion for the selection of respondents was chosen. They were semi-structured as well. The written self-reflections, on the other hand, were completely unstructured, and no criteria were chosen here.

Feedback. After reading the text, students have the opportunity to comment on the text and the author's presentation. This feedback is completely voluntary, but it is very important for the authors. Authors often express the need for feedback. It allows them to develop further and, quite often, deepen their self-reflection. It often becomes a motivation. Feedback can, among other things, confirm the rightness of their direction, prove the communicability of their texts, and assure the feeling of security. Thus, it helps to eliminate the author's expectations of negative reactions.

The game. The progress coming from many years of experimentation, self-reflection, and publication of ideas gradually leads to the discovery of the game as such. ${ }^{29}$ Within the self-reflection, the group of authors describes the phenomenon of the game as such, or they talk about situations where they find themselves simply having fun just because of the activity itself. Some of the authors even understand the game as the most important part of the authorial work.

Challenge. Some authors understand authorial reading as a challenge or a stimulus. In the beginning, they are aware of the fact that writing, public reading, or performing generally do not belong to one of their strengths or favourite and sought-after activities. Later, however, they want to overcome this, and, in most cases, they succeed.

Self-knowledge. After several public readings, the authors describe better self-knowledge, that is, to a greater extent, they notice content and expressions that they have not yet perceived or paid such attention to, and they are able to reflect upon them all.

Problem solving / therapy. As we have already described above, authors often look for answers through their texts, solve their dilemmas and problems, or try to cope with something. More than once in these situations, they choose the technique of 'solving it by writing it down'. The subsequent reading of the text helps them to close the whole matter.

\section{Personality Overlap of the Phenomenon of Authorial Reading}

The categories indicate the suitability of including authorial reading among the study disciplines of personality development. Another finding was that only long-term students can observe the development of understanding of concepts and, at the same time, a qualitative change in the

29 Cf. Stanislav SUDA, Sebereflexe - základ studia dialogického jednání, in: ACORát, 2 (1), Brno: Masarykova univerzita v Brně, 2013, pp. 3-10. 
development of written self-reflection based on verified experience. And really good research requires long-term monitoring. In the case studies within the research into the phenomenon of dialogic acting, this development is captured in those cases that are researched for at least 10 years (case studies Jana, Tomáš, Slávek, Zuzana, Pepíček). ${ }^{30}$ Based on repeated and reflected experience with this phenomenon, a way of thinking about personality content or topics is evolving. In other words, the importance of self-reflection increases.

If we deal with the topic of self-reflection and its development or cultivation, we meet the personal and ethical level of the way of thinking of each individual. ${ }^{31}$ Existing research investigations point to the importance of self-reflection. I deliberately emphasise self-reflection - as a testimony of the continuous process of cultivation of personality maturation. Self-reflection is often interpreted, in a positivist way of thinking, as a closed form. It is an artifact intended for evaluation, instruction, effective use: 'The goal is to evaluate oneself, decide what should be changed and how to do it, choose a strategy for the future.' ${ }^{32}$ Based on long-term research, this proves to be disadvantageous. The path to an authentic discovery of inner motives and self-reflection on the basis of an unexpected experience is a long-term one. It requires a safe atmosphere, an independent choice of discipline, and, especially, time. Therefore, the concept of the meaning of self-reflection as 'an awareness of the contents of one's consciousness, personality characteristics, as well as the results of background actions, respectively the results of actions in confrontation with moral norms or, at least, images of the ideal self', ${ }^{33}$ appears to be a more familiar one.

\section{Conclusion}

Unfortunately, research into the phenomenon of authorial reading was interrupted in 2018 and 2019 for personnel reasons, and thus the continuity of research of the self-reflection in the case of more advanced students was disrupted. Due to the coronavirus situation in 2020, students have not yet been able to return to leisure time studies, but, in twelve cases, they repeatedly show interest in continuing their studies.

The aim of this study is to outline the possibilities of a truly participatory and partnership way of studying personality disciplines as a non-directive approach, of which the result is only the testimony of participants. In this respect, the study of the phenomenon is conditioned by the interest of the participants, and therefore it is not possible to build the research on interpretive models or on assessing the effectiveness of individual components of the means of expression. The essence of long-term research is the authorship which is reflected in the feedback of listening students. It is aimed at the formation of self-reflection, not at interpretive skills which lead to an effective use (learning, commercial, artistic goals).

Authorial reading also has an experimental form at the clinical workplace in a small school: in his dissertation ${ }^{34}$ Josef Nota outlined the possibilities of experimental drama in primary school education. At present, he is expanding his research in the same school in the area of authorial reading. Together with an extensive archive of self-reflection concerning students of pedagogical disciplines of the University of South Bohemia in České Budějovice, a comprehensive picture of

30 Cf. Stanislav SUDA, Experimentální dramatika, České Budějovice: Episteme, 2017.

31 Cf. Horst HEIDBRINK, Psychologie morálního vývoje, Praha: Portál, 1997.

32 Jan PRŮCHA, Eliška WALTEROVÁ and Jiří MAREŠ, Pedagogický slovník, Praha: Portál, 1995, p. 196.

33 Vladimír SMÉKAL, Pozvání do psychologie osobnosti, Brno: Barrister \& Principal, 2004, p. 353.

34 Cf. Josef NOTA, Dialogické jednání jako možnost rozvoje osobnostních dispozic učitele. České Budějovice, 2014. Dissertation (Ph.D.). University of South Bohemia in České Budějovice, Faculty of Education. Thesis supervisor Assoc. Prof. Stanislav Suda. 
the pedagogical possibilities of this discipline is created.

Especially, I would like to thank Mgr. Renáta Mikulová for cooperation and analysis of data from the archive of self-reflections and to careful opponents who, with honest work, help to clarify the research line of long-term monitoring of this phenomenon.

\section{Contact:}

Assoc. Prof. Dr Stanislav Suda

University of South Bohemia in České Budějovice,

Faculty of Theology,

Department of Pedagogy

Kněžská 8, 370 01, České Budějovice.

suda@tf.jcu.cz 